\title{
Spatial assessment of artisanal fisheries and their potential impact on the seabed: the Cap de Creus regional case study (northwestern Mediterranean Sea)
}

\author{
Ariadna Purroy ${ }^{1}$, Susana Requena ${ }^{1}$, Josep-Maria Gili ${ }^{1}$, Antonio Canepa ${ }^{1}$, Rafael Sardá ${ }^{2}$ \\ ${ }^{1}$ Department of Marine Biology, Institute of Marine Science (CMIMA-CSIC), Passeig Marítim de la Barceloneta, 37-49, \\ 08003 Barcelona, Spain. E-mail: apurroy@icm.csic.es (AP), srequena@icm.csic.es (SR), gili@icm.csic.es (JMG) \\ canepa@icm.csic.es (AC) \\ ${ }^{2}$ Centre d'Estudis Avançats de Blanes, CSIC, Carrer d'accés a la cala Sant Francesc, 14, 17300 Blanes, Girona, Spain. \\ E-mail: sarda@ceab.csic.es
}

\begin{abstract}
Summary: The northwestern Mediterranean region faces two contrasting realities: intensive fishing activity and a rising awareness among citizens of the need to protect ecologically important areas. In NE Spain, a large portion of the Cap de Creus area will be declared a Natura 2000 offshore site, establishing a large Marine Protected Area. This study examines the spatial distribution of artisanal fisheries and their potential impact on key vulnerable ecosystem components (KVECs) in the region. Data collection is based on a questionnaire-based survey in the absence of better records. An integrative map showing potential cumulative impact values for the Cap de Creus region was developed, including fishing gear pressure on selected KVECs. The most potentially impacted areas were found along the coast and on canyon margins. Results showed that different types of fishing gears converge, implying a higher impact on certain benthic communities and KVECs, with the greatest spatial coverage in coralligenous areas, Posidonia beds and maërl beds. When fishing log book and vessel monitoring system data are not available, the use of fishermen surveys linked to geographical information system tools can provide fundamental information for further implementation of effective measures for ecosystem-based management aimed at improving conservation of marine benthic ecosystems.
\end{abstract}

Keywords: benthic communities; fishery management; Mediterranean; marine protected area; GIS; métier.

Evaluación espacial de la pesca artesanal y su impacto potencial sobre el fondo del mar: estudio regional del Cap de Creus (Mediterráneo noroccidental)

Resumen: El Mediterráneo noroccidental se enfrenta con dos realidades contrastadas: una actividad pesquera intensa y una creciente conciencia entre los ciudadanos de proteger zonas de importancia ecológica. En el noroeste de España, una gran parte del área del Cap de Creus será designada como una región Red Natura 2000 Alta Mar estableciendo así una gran Area Marina Protegida. Este estudio examina la distribución espacial de la pesca artesanal y su impacto potencial sobre componentes claves del ecosistema en vulnerabilidad (KVEC, por sus siglas en inglés). Los datos usados en este análisis provienen de encuestas basadas en cuestionarios que representan la mejor información disponible. Se ha desarrollado un mapa integrativo mostrando los valores del impacto cumulativo potencial para el Cap de Creus, incluyendo la presión de artes de pesca en los KVECs seleccionados. Las áreas potencialmente más impactadas se encontraron a lo largo de la costa y en los márgenes del cañón submarino. Los resultados mostraron que los diferentes tipos de artes de pesca convergen, lo que implica un mayor impacto en ciertas comunidades bentónicas como las zonas coralígenas, las praderas de Posidonia y los fondos de maërl que son los componentes clave del ecosistema en vulnerabilidad con mayor cobertura espacial. Cuando los datos de la bitácora y del sistema de localización de buques no están disponibles, el uso de encuestas a pescadores vinculado a sistemas de información geográficos (SIG) puede proporcionar información fundamental para aplicar medidas eficaces para la gestión del ecosistema, y mejorar así la conservación de los ecosistemas marinos bentónicos.

Palabras clave: comunidades bentónicas; gestión pesquera; Mediterráneo; Área Marina Protegida; SIG; métier.

Citation/Como citar este artículo: Purroy A., Requena S., Gili J.-M., Canepa A., Sardá R. 2014. Spatial assessment of artisanal fisheries and their potential impact on the seabed: the Cap de Creus regional case study (northwestern Mediterranean Sea). Sci. Mar. 78(4): 449-459. doi: http://dx.doi.org/10.3989/scimar.04000.21A

Editor: V. Stelzenmüller.

Received: December 16, 2013. Accepted: September 26, 2014. Published: October 21, 2014.

Copyright: () 2014 CSIC. This is an open-access article distributed under the Creative Commons Attribution-Non Commercial Lisence (by-nc) Spain 3.0. 


\section{INTRODUCTION}

The European policies regarding biological conservation (mainly the Habitats and Birds Directives and, more recently, the Marine Strategy Framework Directive) strongly encourage the development of marine protected areas (MPAs) (IEEP \& NRDC 2008). MPAs have been envisaged as a potential tool for conservation and safeguarding of the structure and function of marine systems against most anthropogenic activities that contribute to the decline of living resources (Colloca et al. 2004, Griffiths et al. 2007, Guidetti et al. 2010). Further management of MPAs must reconcile the human pressure on these sites with their functional integrity.

Fisheries constitute one of the most important uses of the seas. Two of the most important ecosystem services observed in the marine environment (food production and maintenance of biological condition) are affected by fisheries. Fishing activities play a role in habitat destruction and accidental mortality of non-target species, changing ecosystem functioning and evolutionary shifts in demography of populations (Pikitch 2004). Benthic habitats are mostly pressured by benthic fishing that involves mobile gears producing physical impacts on the seabed and on its biota (Tillin et al. 2006, De Juan et al. 2007, Hinz et al. 2009).

The EU Mediterranean fleet includes a large fraction $(80 \%)$ of artisanal fisheries (COM 2002). They are generally defined as traditional fisheries involving fishing households, using a relatively small amount of capital and energy and relatively small fishing vessels, making short fishing trips close to shore, and mainly supplying local consumption (FAO 2005-2012). In the Mediterranean, fishermen's local knowledge determines the seasonal effort according to species behaviour and abundance throughout the year (Stelzenmüller et al. 2007), segregating the impacts of habitats in a patchy distribution and delimiting the fishing footprint. Fishing footprint can be estimated by the use of vessel monitoring system (VMS) data and information on landings. The use of the VMS can facilitate conservational aspects in management by georeferencing fishing grounds, determining fishing pressures and relating local knowledge to practice. However, in artisanal fisheries, implementing VMS is especially difficult because artisanal boats usually do not exceed $15 \mathrm{~m}$ length, so they are not obliged to use this system. Consequently, the precise location of their fishing activities is neither recorded nor monitored, resulting in a lack of reliable data on the spatial coverage of their activities. An alternative approach to provide reliable figures of fishing grounds is through direct interviews with fishermen (e.g. questionnaire-based surveys) gathering all the relevant information (Stelzenmüller et al. 2007, De Freitas and Tagliani 2009, Forcada et al. 2010).

The Mediterranean, like other regions of Europe, faces a problem of habitat conservation (Stergiou et al. 1996, Guidetti et al. 2010). Under this scenario, the European Comission (EC) Natura 2000 network intends to ameliorate the loss of biodiversity caused by human activities and to restrain certain activities to safeguard the integrity of Sites of Community Interest (SCI). The Cap de Creus offshore area, a SCI since 2006 (Gili et al. 2011, www.indemares.com), is in the process of becoming a new Natura 2000 offshore MPA, thus increasing the protected area of European marine ecoregions. The Cap de Creus hosts an outstanding diversity of marine benthic habitats in which valuable key vulnerable ecosystem components (KVECs) have been identified (Gili et al. 2011). Recent research in Mediterranean submarine canyons close to the Cap de Creus coast revealed rich habitats with a high degree of endemism (Orejas et al. 2009, Gili et al. 2011), indicating that these hotspots of biodiversity might play an important role in providing portions of migration routes and nurseries. During the last few decades, fishing pressure has increased in this area (Gómez et al. 2006) but little information is available on the spatial assessment of its potential impact. During the evaluation phase of the Cap de Creus region to assess its potential interest for conservation, recorded images from remotely operated vehicles (ROVs) and manned submersibles were used. High abundance of cables and abandoned fishing gears was observed in the videos, demonstrating a high impact of these fishing activities on the littoral zone, continental shelf and slope (Gili et al. 2011, Sardá et al. 2012).

The future management of this MPA area is thought to be based on the ICES 2005 ecosystem approach to management, following modern management tendencies developed in ICES 2013 and 2014. One of its main management principles is to use scientific knowledge, so we started a rigorous analysis to determine the state of the Cap de Creus benthic habitats (Gómez et al. 2006, Orejas and Gili 2009, Gili et al. 2011, Sardá et al. 2012), including fishing gear pressure on them, in the best possible way. A spatial fisheries data map was needed to gain a comprehensive view on the usage and distribution of the artisanal fishing effort on this future Natura 2000 MPA area. To develop it and to estimate different potential cumulative impacts of artisanal fishing gears on KVECs, we used the Cap de Creus' benthic assessment and questionnaire-based surveys from fishermen as the best available information to date. The main objective of the present study is to identify and quantify the potential cumulative impact value of artisanal fishing gears on the benthic environment, to determine the habitat distribution of KVECs, and to provide a geographical representation of the potential spatial distribution of fishing gears with a view to informing further decision making within a future ecosystem approach to management implementation for the region.

\section{MATERIALS AND METHODS}

\section{Study area}

The littoral region of the Cap de Creus was the first marine-terrestrial park established in Catalonia, and it is located at the easternmost part of the Iberian Peninsula. The park covers a total area of 13886 ha, of which 10813 ha belongs to the terrestrial sector and 
3073 ha to the marine sector. The Cap de Creus Natura 2000 protection range is intended to extend the area of protection to approximately 90000 ha $\left(900 \mathrm{~km}^{2}\right)$ of offshore waters, covering the shelf, the shelf-break and the head of a submarine canyon in the region.

Since 2003, the benthic habitats of the Cap de Creus (littoral zone, continental shelf and submarine canyon) have been studied (Orejas and Gili 2009, Gili et al. 2011, Sardá et al. 2012). Several European (INTERREG, HERMES) and national (DEEPCORAL) projects have provided the basis for a better understanding of the ecology in the area. The LIFE+INDEMARES Project (www.indemares.es) compiled and developed new information on the physical, biological and ecological characteristics of the area, mainly on the continental shelf and the submarine canyon margins. As a result, many outstanding habitats have been identified, some of which have been georeferenced and catalogued as KVECs (Gili et al. 2011, Sardá et al. 2012). Many of these KVECs often contribute to the three-dimensionality of an otherwise mainly flat substrate, enhancing the complexity of niches and habitats, such as rocky bottoms covered by coralligenous communities, maërl beds on top of muddy or sandy detritic environments or shallower environments, such as seagrass beds (Posidonia oceanica, Cymodocea nodosa) and or algae, all of which increase the diversity of sessile species. The presence of a submarine canyon in the area increases the ecological importance of the entire region. Plankton and benthic communities in the canyon benefit from a high concentration of particles as a consequence of strong current regimes (García et al. 2008, Tesi et al. 2010), thus increasing the presence of fish, seabird and cetacean species which use it as feeding ground (Gili et al. 2011, Würtz et al. 2012). Cold-water corals provide habitat for juveniles and larvae of several fish species, some of them with high commercial value, consequently acting as a refuge from fishing pressure and allowing the recovery of depleted stocks (Freiwald and Roberts 2005).

\section{Data structure, data collection and analysis}

The study area was divided into a $500 \times 500 \mathrm{~m}$ cell grid, covering a surface of $891.25 \mathrm{~km}^{2}$, practically the entire area to be protected as an MPA. The cell grid provides harmonization and reduces the complexity of spatial datasets. At each cell, collected values included a) the associated qualitative marine data (fishing zone, bottom quality, habitats and KVECs), and b) the assigned values from fishermen surveys on the potential impact of different gears on the seafloor. Data were associated with the regional cartography to obtain a final map of potential cumulative fisheries impact through questionnaire-based surveys and spatial analysis using GIS (ESRI ArcGIS ArcInfo v10). An expert panel assessment was used to generate different weights accounting for the impact of different fishing practices on the benthic environment.

\section{Ecological data}

Two maps were produced within this section: a) the habitat description of the study area according to the European Nature Information Systems classification (EUNIS, http://eunis.eea.eu.int/index.jsp), used as a standard international framework for defining the benthic communities (Table 1), and b) the most outstanding elements in these habitats, their KVECs identified through image analysis (Fig. 1)

The benthic cartography of the study area was obtained by combining classical grabbing techniques with imaging methods. The entire MPA region was separated into three main areas of analysis: the littoral zone, the continental shelf and the canyon head. The littoral zone and part of the continental shelf were analysed with grabbing methods and a subsequent identification of their components and ROV transects with quantification of some key landscape species. A cartographical representation can be found in Sardá et al. (2012). The deeper parts of the continental shelf

Table 1. - List of habitats to EUNIS equivalence. (Littoral cartography obtained from Sardá et al. (2012); continental shelf cartography extracted from Gili et al. (2011)).

\begin{tabular}{|c|c|c|c|}
\hline Littoral cartography & Continental shelf cartography & EUNIS terminology & Acronym \\
\hline Harbour communities & Harbour communities & Marine Built Environment Communities & MBE \\
\hline Posidonia oceanica meadows & & Posidonia Beds & SM \\
\hline Precoralligenous with sciaphilous algae & Rocks & Infralittoral Rocky Sciaphilic Communities & IRS \\
\hline Precoralligenous with Eunicella spp. & Rocks & & \\
\hline Photophilic algae communities & Rocks & Infralittoral Rocky Photophilic Communities & IRP \\
\hline Coralligenous with Axinella spp. & Rocks & Circalittoral Coralligenous Communities & $\mathrm{CC}$ \\
\hline Coralligenous with Paramuricea spp. & Rocks & & \\
\hline Coralligenous of continental shelf & Rocks & & \\
\hline Beach sands & Littoral sands & Beach Sands Community & BS \\
\hline Littoral fine sands & Littoral sands & Littoral Fine Sands Community & LFS \\
\hline Littoral fine sands (transition facies) & Littoral muddy sands & & \\
\hline Littoral medium and coarse sands & Littoral sands & Littoral Coarse Sands Community & $\mathrm{LCS}$ \\
\hline Littoral sandy mud & Littoral sandy muds & Littoral Sandy Mud Community & LSM \\
\hline Detrital littoral sands & Detrital littoral & Detritic Sand Community & $\mathrm{DE}$ \\
\hline Detrital littoral sands (with maërl) & & & \\
\hline Gravely sands and boulders & & & \\
\hline Detrital littoral sandy mud & Detrital continental shelf & Detritic Mud Community & DL \\
\hline Detrital littoral sandy mud (with maërl) & & & \\
\hline \multirow[t]{4}{*}{ Littoral muds } & Sandy mud continental shelf & Terrigenous Coastal Mud Community & TCM \\
\hline & Continental shelf muds & & \\
\hline & Littoral muds & & \\
\hline & Deep muds & Deep Sea Muds & DSM \\
\hline
\end{tabular}




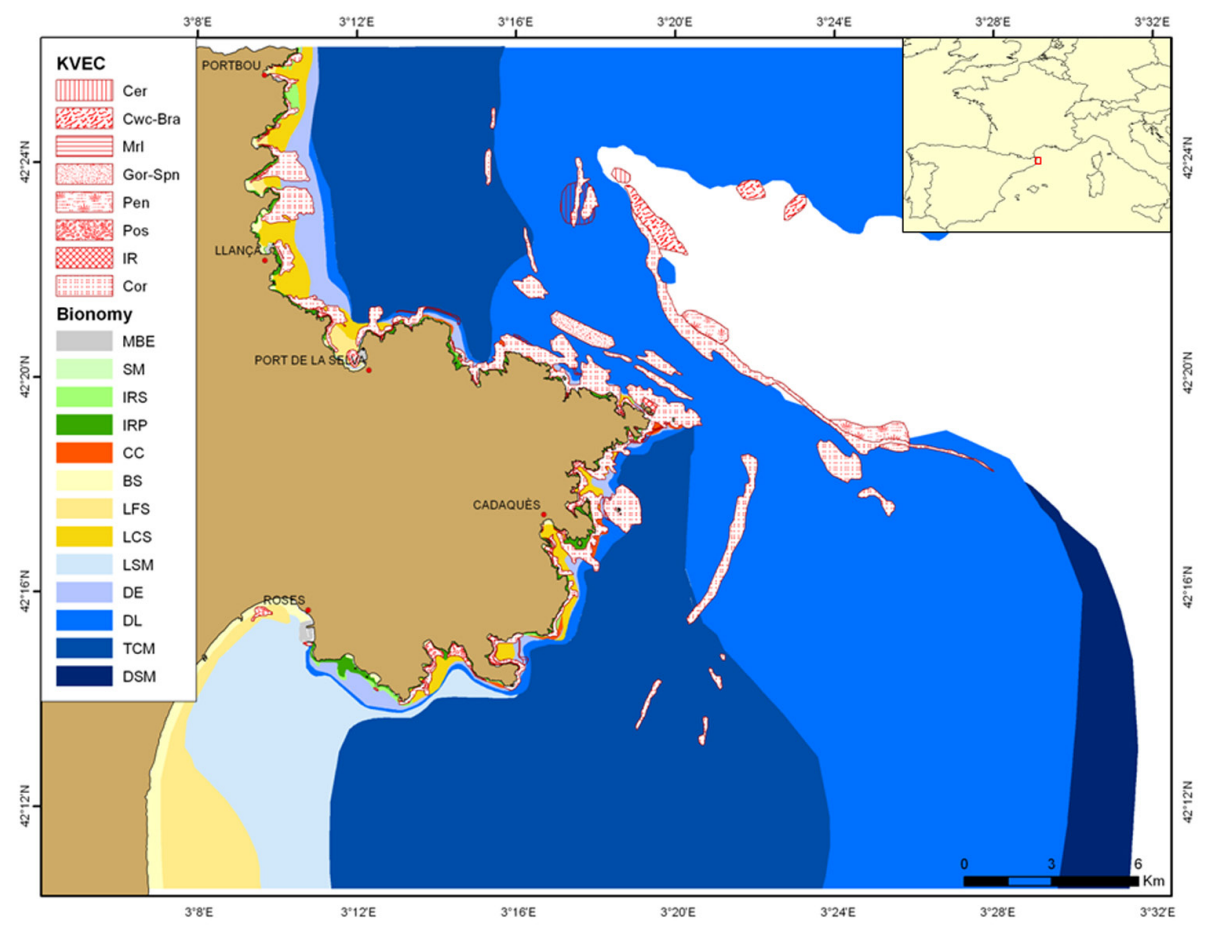

Fig. 1. - Bionomy of the study area based on the EUNIS classification (MBE, Marine Built Environment Communities; SM, Posidonia Beds; IRS, Infralittoral Rocky Sciaphilic Communities; IRP, Infralittoral Rocky Photophilic Communities; CC, Circalittoral Coralligenous Communities; BS, Beach Sands; LFS, Littoral Fine Sands Community; LCS, Littoral Coarse Sands Community; LSM, Littoral Sandy Mud Community; DE, Detritic Sand Community; DL, Detritic Mud Community; TCM, Terrigenous Coastal Mud Community; DSM, Deep Sea Muds) and distribution of the Key Vulnerable Ecosystem Components (Cer, Ceriantharia; Cwc-Bra, cold-water corals and brachiopoda; Mrl, Maërl beds; Gor-Spn, gorgonians and sponge gardens; Pen, Pennatulacea; Pos, Posidonia beds; IR, integral reserve; Cor, Coralligenous communities).

and the canyon head were mainly analysed with ROV images using data obtained from ten oceanographical campaigns associated with the HERMES, DEEPCORAL and INDEMARES projects from 2005 to 2009. This information has been incorporated in the present work. A ROV was used in four of these campaigns, recording videos from the continental shelf (50 to 150 $\mathrm{m}$ depth) and the canyon head (100 to $400 \mathrm{~m}$ depth). This information was completed with Van Veen grab samples (1200 $\mathrm{cm}^{2}$ opening) obtained by revisiting the stations used by Desbruyéres et al. (1972-73) between 70 and 120 m depth off the Cap de Creus. To develop the final bionomic map with the benthic cartography typologies, the map of Desbruyéres et al. (1972-73) was used.

Several benthic communities and spatial components were identified as KVECs: (1) coralligenous communities, (2) maërl beds, (3) Posidonia beds (communities of Posidonia oceanica), (4) gorgonians and sponge gardens, (5) Pennatulacea, (6) Ceriantharia, (7) cold-water corals (Lophelia pertusa, Dendrophilia sp., Madrepora oculata), (8) Brachiopoda and, (9) the Integral Reserve of the protected area within the maritimeterrestrial park. However, the Integral Reserve will be excluded from our fisheries analysis because within this area fishing is prohibited by law.

\section{Artisanal fisheries data}

The artisanal fisheries fleet of the Cap de Creus is composed of fishing vessels with a length of less than $15 \mathrm{~m}$. This fleet does not require reporting of geographical position, so its VMS data were not available. In this study, the artisanal fisheries information was obtained using questionnaires circulated among fishermen between December 2000 and March 2001 as part of the FAO-COPEMED Project (FAO, www.faocopemed.org). These questionnaires compiled information regarding a) the local fishing gear, b) target and accessory species, c) expected number of artisanal fishing units using a gear in a certain period, and d) expected number of artisanal fishermen using a gear in a certain period, fishing season, geographical zone, average depth (max and min) and distance (left to right) which is defined by the concept of métier, to define the real effort invested in a resource (Colloca et al. 2004, Tzanatos et al. 2006, Merino et al. 2008). The qualitative information is available at the COPEMED Project's website. Fishermen were reluctant to give georeferenced positions for their catches and they only provided the geographical area in which the fishing gears were used. The selected data comprise a total of 73 métiers encompassing the fishing activities in the harbours of interest (Port de la Selva, Llançà, Cadaqués, Roses, L'Escala and l'Estartit). For the spatial representation of fishing gears, only the four most common affecting the continental shelf, slope and canyon were selected: a) surface longlines, b) bottom longlines, c) trammel nets and d) gillnets. Other fishing gears acting in the area were rare and mainly coastal (pots, boats or vessel seines, com- 
Table 2. - Results of the expert panel assessment for each of the major fishing gear types active in the study area.

\begin{tabular}{|c|c|c|c|c|c|c|c|c|c|c|c|c|}
\hline & \multirow{2}{*}{$\begin{array}{l}\text { Direct } \\
\text { bottom } \\
\text { impact }\end{array}$} & \multicolumn{2}{|c|}{ Bottom type } & \multicolumn{2}{|c|}{ Seasonality } & \multirow[b]{2}{*}{$\begin{array}{l}\text { Number } \\
\text { of boats }\end{array}$} & \multirow[b]{2}{*}{$\begin{array}{l}\text { Gear's } \\
\text { surface }\end{array}$} & \multirow[b]{2}{*}{ Coverage } & \multirow[b]{2}{*}{$\begin{array}{l}\text { Execution } \\
\text { time }\end{array}$} & \multirow[b]{2}{*}{ Specificity } & \multirow{2}{*}{$\begin{array}{l}\text { Interaction with } \\
\text { seabed (when } \\
\text { abandoned) }\end{array}$} & \multirow[b]{2}{*}{$\begin{array}{l}\text { Impact } \\
\text { value }\end{array}$} \\
\hline & & Soft & Hard & $\begin{array}{c}1-2 \\
\text { seasons }\end{array}$ & $\begin{array}{c}\text { All } \\
\text { year }\end{array}$ & & & & & & & \\
\hline Bottom longline & 2 & 2 & 2 & 1 & 3 & 1 & 3 & 3 & 3 & 1 & 2 & 0.29 \\
\hline Surface longline & 0 & 0 & 0 & 0 & 0 & 1 & 1 & 2 & 3 & 2 & 1 & 0.13 \\
\hline Gillnet & 1 & 2 & 1 & 2 & 2 & 2 & 1 & 2 & 1 & 3 & 2 & 0.24 \\
\hline Trammel net & 3 & 3 & 1 & 2 & 2 & 3 & 2 & 3 & 1 & 3 & 3 & 0.33 \\
\hline
\end{tabular}

bined gillnet-trammel nets, handlines and pole-lines, and miscellaneous gears). A total of 195 fishermen and 161 boats were included in this analysis.

\section{Expert panel assessment: potential cumulative im- pact value}

The impact on the benthic communities of the four major gears used in the area was assessed by a group of experts from two CSIC Institutions (Institut de Ciències del Mar and Centre d'Estudis Avançats de Blanes) with more than 30 years of experience in the area. We defined the gear impact value based on the disturbance to different components of the ecosystem. The four fishing gears assessed were considered as individual fishing impact types and our final aim was to calculate a potential cumulative impact value of the combination of all of them. As there was not enough information to calculate the impact of each gear on each location (individual cell grid), or for each EUNIS classification habitat type, we opted for a general assessment of each fishing gear and consequently the use of the presence/absence of each gear per cell to calculate their potential impact by weighting the overlap of these gears. The impact value of each of the four assessed gears was computed on the basis of 11 different criteria:

(1) Direct bottom impact: gear effect on the bottom produced by physical contact.

(2) Bottom type (soft): mechanical effect of the gear on soft-bottom habitats.

(3) Bottom type (hard): mechanical effect of the gear on hard-bottom habitats.

(4) Seasonality (1-2 seasons): direct effect produced when gears are only used in one or two quarters of the year.

(5) Seasonality (all year): direct effect produced when gears are used throughout the entire year.

(6) Number of boats: number of boats operating with a particular gear.

(7) Gear surface: effect associated as a consequence of the gear's 3D structure.

(8) Coverage: areal extent of the gear in the region.

(9) Execution time: working time of each gear.

(10) Specificity: effect associated with the intended number of target species.

(11) Interaction with seabed (when abandoned): so-called "ghost fishing" when gears are lost or abandoned.

To avoid additive effects and oversimplification, all these 11 criteria were scored for each of the assessed gears from 0 (minimum impact) to 3 (maximum im- pact). This meant that the highest possible score for each gear was computed as 33. The final impact value for each gear was then calculated as the division of each gear's score (sum of each criterion value) by 33 . The contribution of each of the four gears to the final impact value was normalized to 1 on the sum of all the gear values. Thus, we ended up with a potential cumulative impact value per cell that was an additive aggregation of the number of fishing gears acting in a particular grid cell. Table 2 shows the expert panel assessment average value for each criterion for each of the major types of fishing gears used.

For the spatial representation, the Jenks natural breaks algorithm (De Smith et al. 2007) was used to determine the best arrangement of values in different classes. The statistical hypothesis of no differences in the potential cumulative impact value among different KVECs was tested using ANOVA. Data was rank transformed in order to pass ANOVA assumptions. In cases of significant differences, Tukey post-hoc analysis was performed.

\section{RESULTS}

\section{Bionomic data: Habitats and Key Vulnerable Eco- system Components}

According to the EUNIS classification, a total of 13 different habitats were described, representing nearly $75 \%$ of the study area (Fig. 1). Table 3 shows the percentages of spatial coverage of these habitats in a bi-dimensional map. The Detritic Mud Community (DL) and the Terrigenous Coastal Mud Community (TCM) showed the greatest spatial coverage (36.7\% and $21.9 \%$, respectively). The EUNIS habitat characterization includes different bionomic communities under each category that were not considered

Table 3. - Percentage of coverage of each of the described habitats within the study area ("No Habitat Data" corresponds to the surface containing the canyon structure and surrounding areas (see the white area in Fig. 1)).

\begin{tabular}{lc}
\hline \multicolumn{1}{c}{ Habitats } & Coverage (\%) \\
\hline Beach Sands Community & 1.1 \\
Circalittoral Coralligenous Communities & 0.7 \\
Detritic Mud Community & 36.7 \\
Detritic Sand Community & 2.2 \\
Infralittoral Rocky Photophilic Communities & 0.8 \\
Infralittoral Rocky Sciaphilic Communities & 0.7 \\
Littoral Coarse Sands Community & 0.9 \\
Littoral Fine Sands Community & 2.6 \\
Littoral Sandy Mud Community & 3.3 \\
Marine Built Environment Communities & 0.2 \\
Posidonia Beds & 0.8 \\
Terrigenous Coastal Mud Community & 21.9 \\
Deep Sea Muds & 2.7 \\
No Habitat Data & 25.5 \\
\hline
\end{tabular}


Table 4. - Percentage of coverage of the Key Vulnerable Ecosystem Components within the study area.

\begin{tabular}{lc}
\hline Key Vulnerable Ecosystem Components & Coverage $(\%)$ \\
\hline Ceriantharia & 0.43 \\
Cold-water corals and Brachiopoda & 0.78 \\
Maërl & 1.31 \\
Gorgonians and sponges & 0.29 \\
Pennatulacea & 0.7 \\
Posidonia oceanica & 2.46 \\
Coralligenous communities & 10.39 \\
Integral reserve & 0.08 \\
\hline
\end{tabular}

for the purpose of this map. A detailed description of these communities is given by Ros et al. (1985) and Alós (1986) for the infralittoral rock photophilic and sciaphilic communities and Gili et al. (2013) for the rest of the facies in the continental shelf habitats considered.

The most outstanding elements, defined as KVECs, were present in $13 \%$ of the study area. Table 4 shows the percentages of spatial coverage of these elements in relation to the entire area. From major to minor coverage, the KVECs were defined as follows: coralligenous (rocky bottoms), Posidonia beds, maërl beds, cold-water corals and Brachiopoda, Pennatulacea, Ceriantharia, gorgonians and sponge gardens, and the integral reserve. Coralligenous components were the most abundant in the area, showing a patchy distribution on top of various continental shelf communities also hosting small rocky areas (Fig. 1).
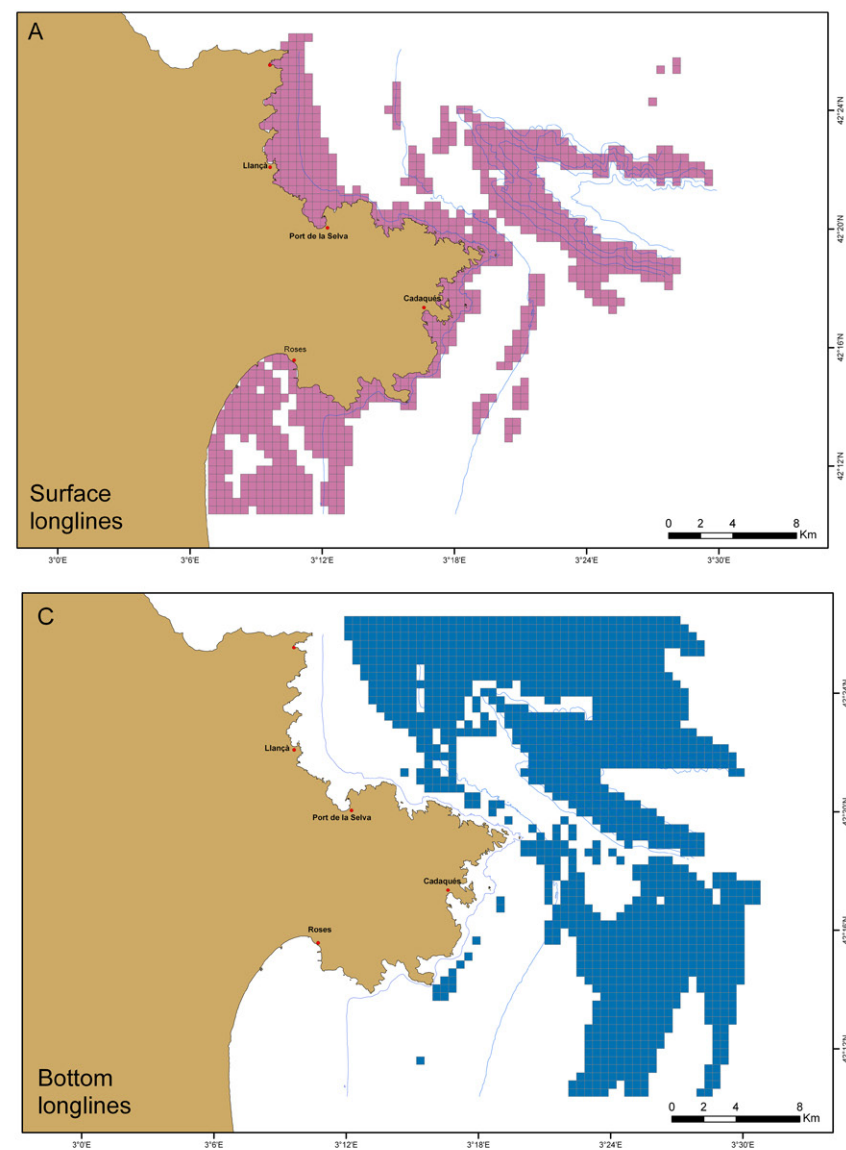

\section{Artisanal fisheries data: fishing gears}

Trammel nets, gillnets and longlines dominated the artisanal fisheries gear types used in the study area. The percentages of coverage of each gear (bearing in mind that several gear types can coincide within the same cell) over the grid were as follows: $34 \%$ for bottom longlines, $31 \%$ for trammel nets, $24 \%$ for surface longlines and 19\% for gillnets. Of the total area, 27\% $\left(314 \mathrm{~km}^{2}\right)$ support only one type of fishing gear activity. The resulting maps for each gear type are shown in Figure 2.

The distribution of the frequencies of overlapping and non-overlapping gear types used as grid frequency numbers (cell counts) is shown in Figure 3. Trammel netters and bottom longliners covered the highest percentage of fishing area with a single gear impact (12.8\% and $8 \%$, respectively), while surface longliners and gill-netters only covered $5.6 \%$ and $0.4 \%$, respectively, as the only gear in a particular area. Areas with convergence of two or three types of fishing gear accounted for different weights depending on the coexisting gear types, since the contribution of each gear might be different. The dominant overlapping of trammel netters and surface longliners $(42 \%)$ and the combination of trammel nets, gillnets and surface longliners (26.9\%) contrasted with the low overlap of bottom longliners, which rarely (3.5\% of cases on average) coincided with two or more gear types (Fig. 4).
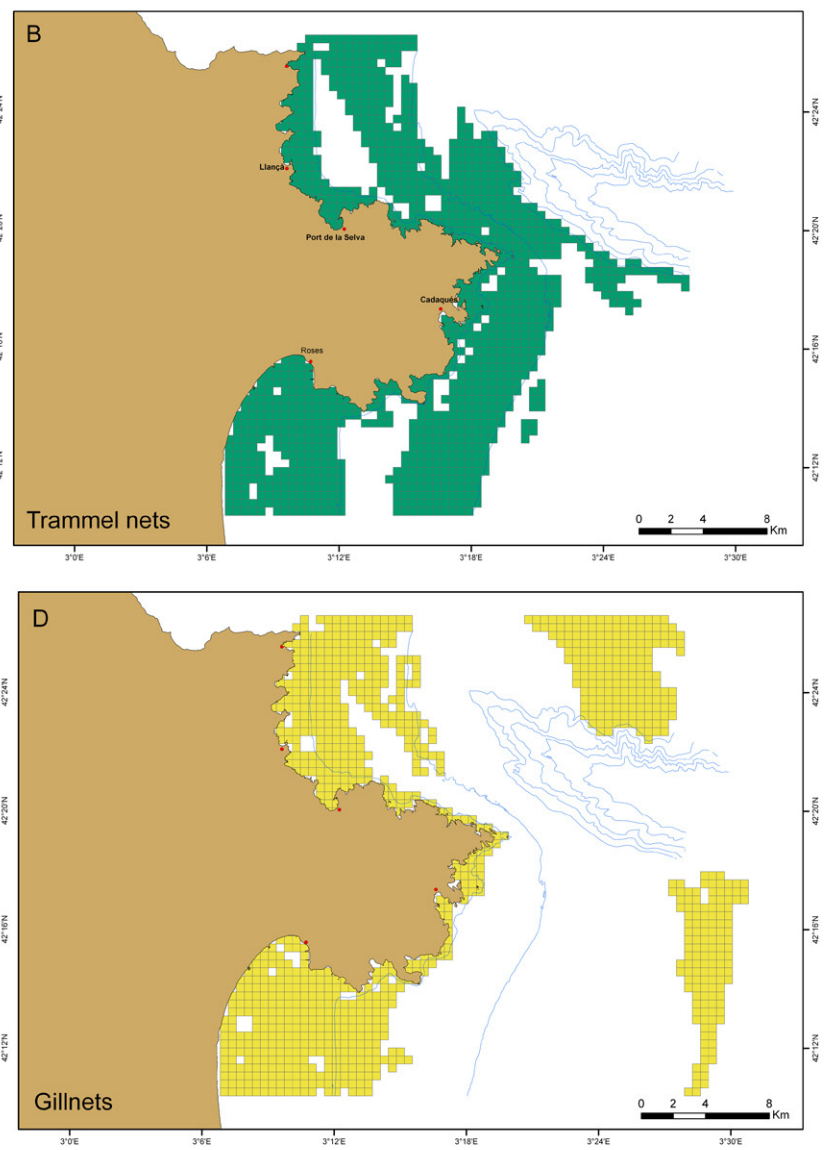

Fig. 2. - Spatial distribution of fishing activity in the study area: (A) surface and (C) bottom longlines, (B) trammel nets and (D) gillnets. 


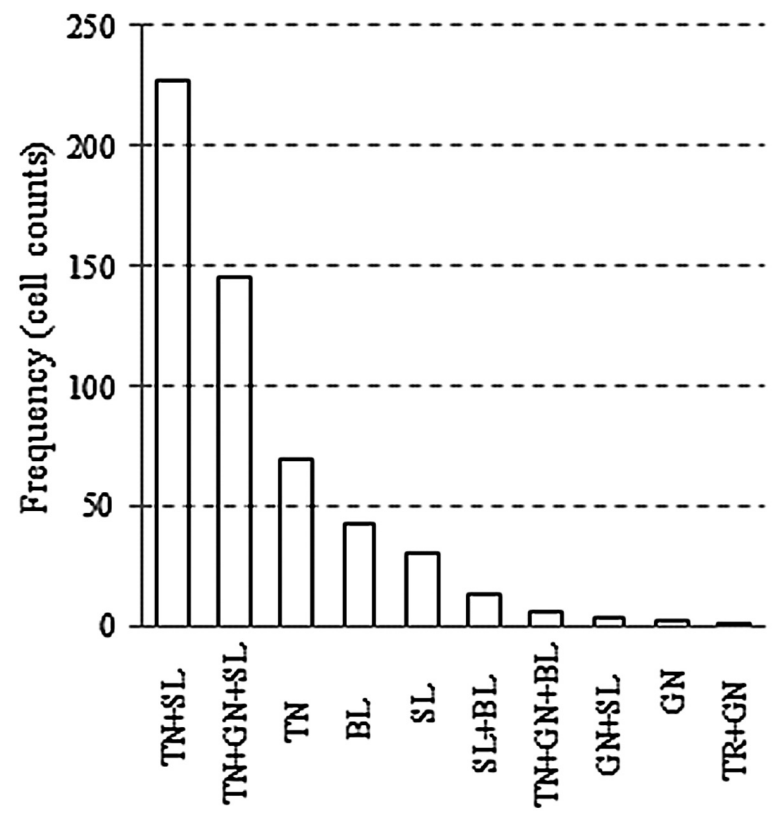

Fishing gears

Fig. 3. - Distribution of the frequencies of overlapping fishing gear types (SL, surface longlines; TN, trammel nets; BL, bottom longlines; GN, gillnets).

\section{Potential cumulative impact value}

The assessment of the fishermen questionnaires provided data for $85 \%$ of the grid cells. Fisheries experts were able to weight the four analysed gear types, producing a score that related the potential impact on

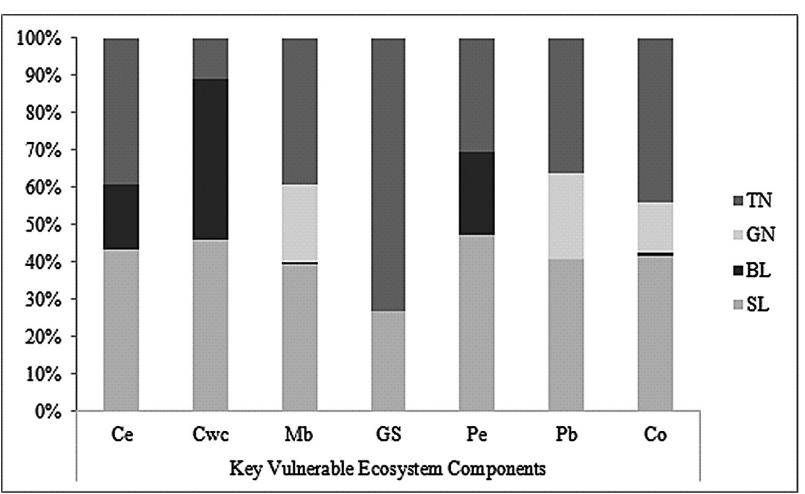

Fig. 4. - Percentage of presence of fishing gears over the total of each KVEC cell (SL, surface longlines; TN, trammel nets; BL, bottom longlines; GN, gillnets).

the benthic environment of each type against the others, ranging from 0 (minor impact) to 1 (major impact) (Table 2). Without considering the spatial extent of fishing activity, bottom longliners and trammel netters were the gear types with the greatest impact on the benthos, with values of 0.29 and 0.33 , respectively, followed by gill-netters (0.24) and surface longliners (0.13). Adding individual scores for each cell in the grid and totaling the four artisanal fishery gear types evaluated, we obtained a figure representing the cumulative impact value (Fig. 5). The final classification involved impact score values divided into four categories according to the Jenks natural breaks algorithm: 0 (absence of fishing activity), low (0.12-0.37), medium (0.37-0.58) and high (0.58-0.87). No zone showing a value of 1 (being impacted by the four gear types in the same grid cell) was found. However, most of the study area (70\%) was

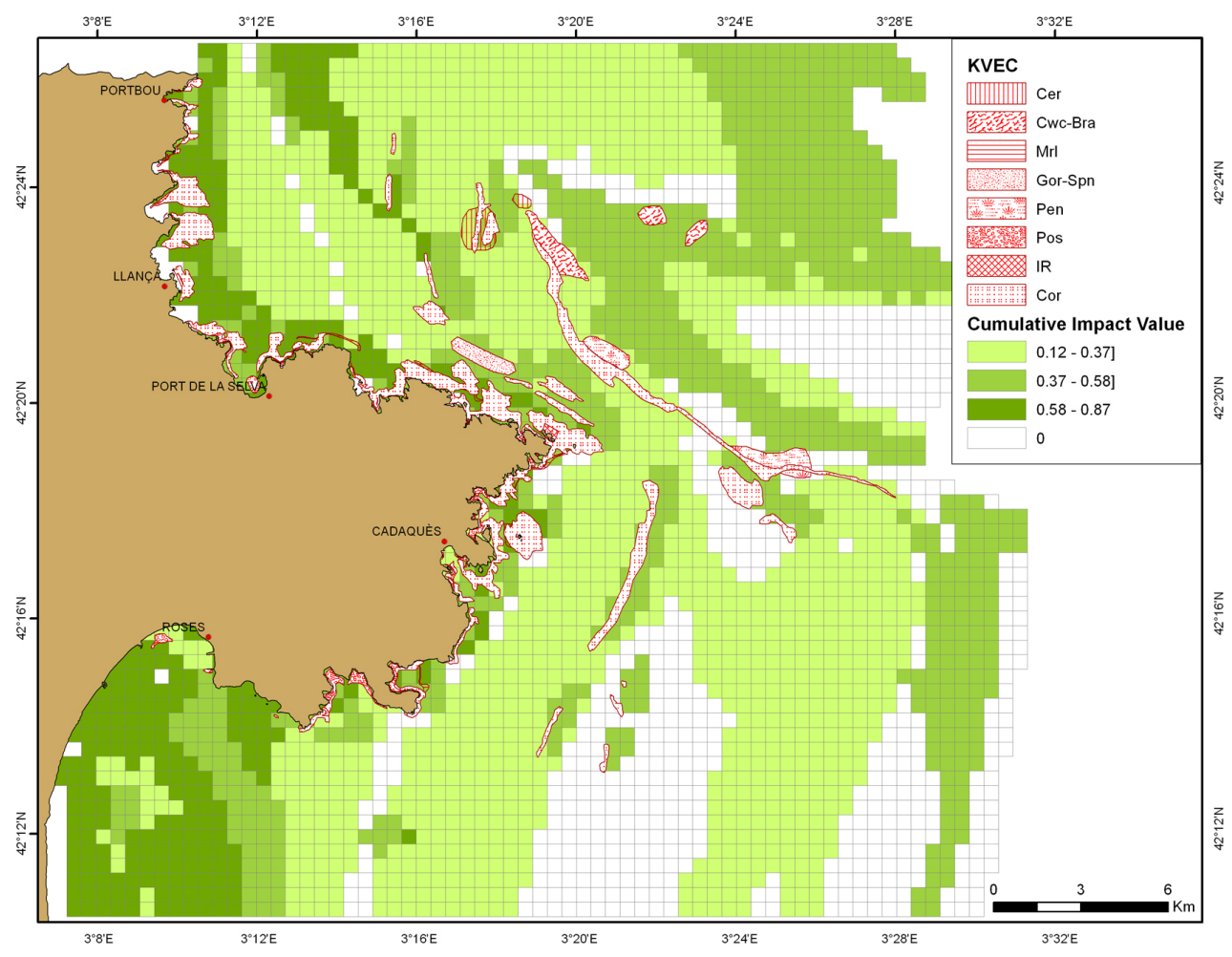

Fig. 5. - Spatial distribution of the cumulative impact value in the study area according to its classification into four categories, and the Key Vulnerable Ecosystem Components. 


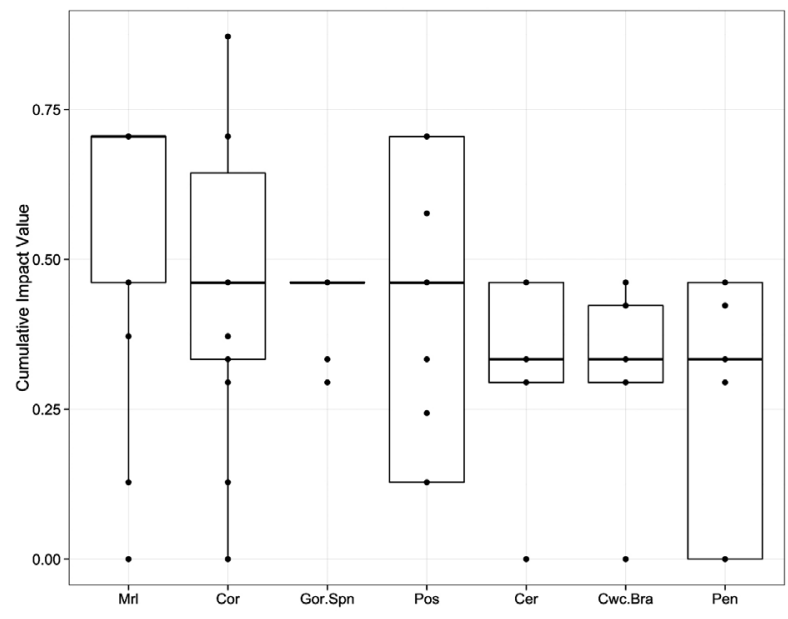

Fig. 6. - Cumulative Impact Value distribution on different KVECs. Grey dots represent observed data. Horizontal (medium) line shows the median, box represents the upper $(75 \%)$ and lower $(25 \%)$ quartiles of the data. Vertical lines represent the greatest and lowest values recorded, excluding the outliers (Cer, Ceriantharia; CwcBra, cold-water corals and Brachiopoda; Mrl, maërl beds; Gor-Spn, gorgonians and sponge gardens; Pen, Pennatulacea; Pos, Posidonia beds; IR, integral reserve; Cor, coralligenous communities).

affected by gear types (from one to three). Once the spatial distribution of the main fishing gears and their degree of impact on the bottoms had been computed, the spatial extent of the KVECs was integrated (Fig. 6). Looking at the presence/absence of fishing gears per KVEC, trammel nets and surface longlines were always present, whereas the other two were only present in some KVECs. The four fishing gears were only present in areas where maërl beds and coralligenous communities were found, whereas trammel nets and surface longlines were the only gears present in areas inhabited by gorgonians and sponges (Fig. 4). The greatest diversity of key communities for conservation purposes was detected in areas between low and medium convergence of different types of fishing gear. Cold-water corals, Pennatulacea, Ceriantharia and gorgonians and sponges were located in areas with low to medium cumulative impact $(32 \%$ and $51 \%$, respectively) in contrast with coralligenous communities and Posidonia beds, which abounded in medium to high potential cumulative value indexes $(48 \%$ and $37 \%$, respectively). The present study identified that $70 \%$ of the Cap de Creus area is more susceptible to fishery impacts. The rotation of fishing gear types throughout the year, already carried out in France, Malta, Calabria and Sicily (Collet 2006), promotes the optimisation of fishing yields while improving the state of marine ecosystems, and is a successful example of management of areas where ecologically important species are found. At this point, mapping fishing pressure emerges as a useful tool for identifying potential areas of conflict, which were those with a relatively high cumulative value $(0.58-0.87)$ and represented $137 \mathrm{~km}^{2}(12 \%$ of the total study area).

Statistical differences were found for the potential cumulative impact value among different KVECs $\left(\mathrm{F}_{6}\right.$ $=8.73$, p-value <0.001). Tukey multiple comparisons showed that the most impacted KVECs in decreasing order were maërl, coralligenous communities, gorgonians and sponges, and Posidonia beds. Pennatulacea, cold-water corals and Brachiopoda, and Ceriantharia had the same median values. Gorgonians and sponges showed a peculiar distribution because they were present only in 3 of the cumulative impact value ranges, two of them being represented by just 1 count (impacted cell) in contrast to the median value $(0.46)$ calculated with 9 counts over 11 observations. Additionally, no 0-impacted cells were obtained for Posidonia beds and gorgonians and sponges, corroborating the higher pressure exerted on these habitats.

\section{DISCUSSION}

The four fishing gears analysed in the present study are the most common artisanal fishing gear types used in the western-central Mediterranean (Coppola 2003, Tzanatos et al. 2006, Cadiou et al. 2009). We estimated the potential impact of these artisanal fisheries on the seabed. Our 11 criteria allowed us to determine the heterogeneous distribution of the combined pressure of these gears over time and space where different metiers overlap. The areas subjected to higher pressure corresponded to both the coastal fringe and those relatively undisturbed by natural processes (i.e. muddy areas) in contrast to areas in the channel between the canyon and the coast, which mostly had coarser sediments, suffering a higher natural disturbance due to currents (Tudela 2000, Gili et al. 2011). The spatial exclusion of each fishing gear type (i.e. trammel nets and surface longlines rarely coincide in space) is possibly due to the incompatibility of the associated fishing methods and the likely consequent spatial exclusion (Aldebert et al. 1993). Bottom longlines appeared to be only present off the coast (in areas at depths greater than about 50 $\mathrm{m})$, although in some areas there was an overlap with trammel nets and gillnets.

All habitats and/or communities can contain smaller and more homogeneous units which can be considered vulnerable components. In some cases, the entire community can also be considered a vulnerable component (such as coralligenous communities). Normally, in our case study, these communities occurred in small patches in a landscape mosaic and scattered amongst larger habitats with which they were associated. The KVECs selected in the present study play important functional roles in the ecosystem. On the continental shelf and the canyon head, the emerging sessile organisms, such as cold-water corals, Pennatulacea, Ceriantharia, gorgonians, sponge gardens and calcareous algae are among the most sensitive species to fishing gear impacts since they all function as key benthic engineer organisms (Cocito 2004). Under this definition, large, erect well-skeletonised mound or branching organisms are considered to host abundant epifauna, providing a fundamental structural framework for the ecosystem (Kaiser et al. 2002, Cocito 2004). To maintain the functional role of bioengineers, it is necessary to conserve dense assemblages (Thrush et al. 1998, Kaiser et al. 2002). At the Cap de 
Creus, cold-water coral species Madrepora oculata and Lophelia pertusa were found to be highly abundant at the margins of the continental shelf between depths of 150 and $400 \mathrm{~m}$, where the steepness of the canyon walls provides natural protection for their development and suitable oceanographic conditions for growth (Orejas et al. 2009). The assessment of the current state of these communities revealed that longline fishing activities might represent a serious threat to their survival, especially on the canyon margins (Fig. 6 ), where these species become accidental catch (Gili et al. 2011), as occurs worldwide (Turner et al. 1999, Tudela 2000, De Juan et al. 2007). On the other hand, in littoral shallow environments, Posidonia beds are spatially complex and biologically productive ecosystems that provide habitat, food and nursery areas essential for a wide range of fish fauna (e.g. Sparidae, Labridae) (Thayer et al. 1975) and they are defined as special conservation areas according to the EC Habitats Directive. In the present study they showed a relatively low percentage of coverage. Furthermore, in the regions where Posidonia beds were present, no cells free of impact were found, suggesting that they are subject to strong fishing pressure. It is predictable that the local megabenthos assemblages will drastically change due to a potential decline in Posidonia beds that will affect the entire ecosystem structure, as previously found in other Mediterranean settings (Tudela 2000, Boudouresque et al. 2009).

The information from the fishermen questionnaires allowed us to represent a spatial map of the artisanal fishing activities in the area showing the overlap of several fishing gears. Obtaining data on artisanal fisheries is not an easy task and the available information is scarce because the fishermen community is not forced to use VMS and they are reluctant to reveal their fishing grounds and activity pattern. The pressure of artisanal fisheries on KVECs over time is assumed to be constant, producing a permanently altered state (Collie et al. 2001). Thus, an entire annual dataset (2000-2001) is of high analytical value and provides the best information possible. However, fishing practices can alter and weaken the complex structure and dynamics of benthic ecosystems and associated fish species (Tudela 2000) and if the area is going to be managed under an MPA figure, impacts should be alleviated as much as possible.

Cumulative impact indexes based on the best scientific information possible have been developed to support maritime spatial planning and ecosystem-based management (Halpern et al. 2008). Science should improve its capacity to characterize, if not quantify, uncertainty in assessments and predictions and to effectively communicate this uncertainty to managers and the public (Boesch 2006). In the absence of a planned scientific methodology, compiling available information and translating it into advantageous knowledge is the best procedure. For the Cap de Creus region, in the absence of more sophisticated data that allow us to calculate fishing intensity per cell, we combined the potential cumulative impact value with the KVEC distribution in a cartographical way.
The potential impact affected especially Posidonia and maërl beds, covering $13 \%$ of the areas with KVECs; on the other hand, low potential cumulative impact values were associated with the majority (nearly two-thirds) of the study area, where Pennatulacea, gorgonians and sponges and cold-water corals were found. Therefore, a relationship between a higher number of KVECs and a low to medium fishing pressure is clear. This relation supports the fact that the knowledge of benthic characteristics and the current state of these species and communities is essential to ensure the implementation of appropriate preventive measures for the upcoming management, i.e. to enforce protection of KVECs. It is important to note that though maërl obtained the highest median impact score $(0.71)$, the consecutive KVECs in decreasing order were considerably affected, with 0.46 as the median score. Whereas coralligenous communities were the KVEC with the broadest distribution, implying an exposure to the entire impact gradient, Posidonia beds and gorgonians and sponges were narrowly distributed and obtained no 0-impacted cells, thus corroborating the higher pressure exerted on these habitats.

Partitioning of fishing activities arises as an effective approach for habitat conservation. Both areas where one type of fishing gear is used (i.e. parcelling) and areas shared seasonally by two or more (i.e. considering the target species' behaviour) have been seen to be useful to preserve the ecosystem and to avoid possible conflicts among fishing sectors (Kaiser et al. 2002, Morgan and Chuenpagdee 2003, Grau 2008). Fishermen rotate among their best fishing grounds to prevent crowding, implying that they self-regulate for their own benefit and for the prevention of possible arguments among colleagues (Aldebert et al. 1993, Scott 1993, Bonzon 2000,). Agreements for sharing access to resources over space and time are common (Bonzon 2000, Morgan and Chuenpagdee 2003). Significant contributions of this benefit in the Mediterranean have been demonstrated (Scott 1993, Lleonart et al. 1998, Turner et al. 1999, Gómez et al. 2006), as has also been reported in the Chilean scenario, considering fishermen's behaviour, traditional knowledge, property rights and the equitable use of marine resources (Castilla 2000, Fernández and Castilla 2005). To facilitate fishermen's participation (e.g. through questionnaires, which have proved to be scientifically meaningful) in the local management of the area and provide them with a sense of ownership, communities should be responsible for managing a delimited area, known as territorial use rights in fisheries (Castilla 2000). Additionally, as seen in other fishing communities in Greece, Italy and France, alternative income solutions, such as eco-tourism or involvement in the design of existing or future MPAs, have also proved to be successful (Collet 2006).

Environmental (e.g. currents), socioeconomic (i.e. fishing gear types) and geophysical (e.g. the narrowness of the shelf) components in the study area favour artisanal fisheries as the prevailing activity. The combination of this set of factors has ended in the actual state of KVECs. However, we cannot track past interactions among them or determine the degree to which 
each of them has affected the seabed components; thus, we cannot distinguish areas where, e.g., environmental factors have had a greater influence on the absence/ presence of KVECs than fisheries pressure. This limitation does not prevent the present analysis from providing an approach to be used for artisanal fisheries to identify areas which are prone to conflict, are subject to greater fishing pressure or host relatively well preserved benthic communities. The possible use of the developed maps for the involvement of fishermen and other stakeholders in workshops could be of real application, helping to diminish possible conflicts and illustrating the importance of spatial data at relevant scales for decision making.

Artisanal fisheries are the best alternative for achieving a sustainable use of coastal marine resources (Pauly 2006) and in the case of Cap de Creus they also represent part of the cultural heritage. Nevertheless, it is important to consider that ecological impacts do not depend entirely on the size of fishing vessels but are more strongly related to the fishing gear type and habitat features, as observed in studies addressing a small-scale fishery in Baja California (Shester and Micheli 2011).

\section{CONCLUSIONS}

An integrative map showing the potential cumulative impact values of the four most common fishing gears in the Cap de Creus region was developed based on fishermen information and permitted the estimation of fishing pressure on the selected KVECs from the local benthic communities. The method developed was used to identify the fishing gears exerting the pressures and the KVECs suffering the greatest pressure. Mapping the fishing pressure is a useful approach to identify the potentially most impacted KVECs and areas, as well as areas of conflict among fishermen. The approach presented here could be greatly improved by fishing activity records (VMS) or by a direct contribution from fishermen through questionnaire-based interviews.

\section{ACKNOWLEDGEMENTS}

This work was funded by the LIFE+INDEMARES Project (LIFE07/NAT/E/000732). We would like to thank our colleagues at the benthic ecology lab at the ICM-CSIC for their assistance and the anonymous referees for their constructive comments.

\section{REFERENCES}

Aldebert Y., Recasens L., Lleonart J. 1993. Analysis of gear interactions in a hake fishery: The case of the Gulf of Lions (NW Mediterranean). Sci. Mar. 57(2/3): 207-217.

Alós M.C. 1986. Anélidos Poliquetos del Cabo de Creus (Alt Empordà). $\mathrm{PhD}$ thesis, University of Barcelona, Spain.

Bonzon A. 2000. Development of economic and social indicators for the management of Mediterranean fisheries. Mar. Freshw. Res. 51: 493-500. http://dx.doi.org/10.1071/MF99088

Boesch D.F. 2006. Scientific requirements for ecosystem-based management in the restoration of Chesapeake Bay and Coastal Louisiana. Ecol. Eng. 26: 6-26. http://dx.doi.org/10.1016/j.ecoleng.2005.09.004

Boudouresque C.F., Bernard G., Pergent G., et al. 2009. Regression of Mediterranean seagrasses caused by natural processes and anthropogenic disturbances and stress: a critical review. Bot. Mar. 52(5): 395-418.

http://dx.doi.org/10.1515/BOT.2009.057

Cadiou G., Boudouresque C.F., Bonhomme P., et al. 2009. The management of artisanal fishing within the Marine Protected Area of the Port-Cros National Park (northwest Mediterranean Sea): a success story? ICES J. Mar. Sci. 66: 41-49. http://dx.doi.org/10.1093/icesjms/fsn 188

Castilla J.C. 2000. Roles of experimental marine ecology in coastal management and conservation. J. Exp. Mar. Biol. Ecol. 250: 3-21. http://dx.doi.org/10.1016/S0022-0981(00)00177-5

Cocito S. 2004. Bioconstruction and biodiversity: their mutual influence. Sci. Mar. 68(Suppl. 1): 137-144. http://dx.doi.org/10.3989/scimar.2004.68s1137

Collet S. 2006. Halieutical commons in the Mediterranean: holistic and engendered governance forms for eco-social development pathways. Social Science Information 45: 411-431. http://dx.doi.org/10.1177/0539018406066534

Collie J.S., Hall S.J., Kaiser M.J., et al. 2001. A quantitative analysis of fishing impacts on shelf-sea benthos. J. Anim. Ecol. 69(5): 785-798. http://dx.doi.org/10.1046/j.1365-2656.2000.00434.x

Colloca F., Crespi V., Cerasi S., et al. 2004. Structure and evolution of the artisanal fishery in a southern Italian coastal area. Fish. Res. 69: 359-369. http://dx.doi.org/10.1016/j.fishres.2004.06.014

COM. 2002. Communication from the Commission to the Council and the European Parliament laying down a Community Action Plan for the conservation and sustainable exploitation of fisheries resources in the Mediterranean Sea under the Common Fisheries, Brussels.

Coppola S.R. 2003. Inventory of Artisanal Fishery Communities in the Western-Central Mediterranean. FAO-COPEMED technical report, Rome.

De Freitas D.M., Tagliani P.R.A. 2009. The use of GIS for the integration of traditional and scientific knowledge in supporting artisanal fisheries management in southern Brazil. J. Environ. Manage. 90: 2071-2080. http://dx.doi.org/10.1016/j.jenvman.2007.08.026

De Juan S., Thrush S., Demestre M. 2007. Functional changes as indicators of trawling disturbance on a benthic community located in a fishing ground (NW Mediterranean). Mar. Ecol. Prog. Ser. 334: 117-129.

http://dx.doi.org/10.3354/meps334117

De Smith M.J., Goodchild M.J., Longley P.A. 2007. Univariate classification schemes in Geospatial Analysis -A Comprehensive Guide, 3rd ed., 55 pp.

Desbruyères D., Guille A., Ramos J. 1972-1973. Bionomie benthique du plateau continental de la côte catalane espagnole. Vie Milieu 23: 335-363.

FAO. 2005-2012. Fisheries and Aquaculture topics. Small-scale and artisanal fisheries. Topics Fact Sheets. Text by Jan Johnson. In: FAO Fisheries and Aquaculture Department [online]. Rome. Updated 27 May 2005

Fernández M., Castilla J.C. 2005. Marine Conservation in Chile: Historical Perspective, Lessons, and Challenges. Conserv. Biol. 19: $1752-1762$ http://dx.doi.org/10.1111/j.1523-1739.2005.00277.x

Forcada A., Valle C., Sánchez-Lizaso J.L., et al. 2010. Structure and spatio-temporal dynamics of artisanal fisheries around a Mediterranean marine protected area. ICES J. Mar. Sci. 67: 191-203. http://dx.doi.org/10.1093/icesjms/fsp234

Freiwald A., Roberts J.M. 2005. Cold-water Corals and Ecosystems. Springer-Verlag Berlin Heidelberg, The Netherlands. http://dx.doi.org/10.1007/3-540-27673-4

García R., van Oevelen D., Soetaert K., et al. 2008. Deposition rates, mixing intensity and organic content in two contrasting submarine canyons. Prog. Oceanogr. 76(2): 192-215. http://dx.doi.org/10.1016/j.pocean.2008.01.00

Gili J.M., Madurell T., Requena S., et al. 2011. Caracterización física y ecológica del área marina del Cap de Creus. Informe final área LIFE+INDEMARES (LIFE07/NAT/E/000732). Instituto de Ciencias del Mar/CSIC (Barcelona). Coordinación: Fundación Biodiversidad, Madrid, $272 \mathrm{pp}$.

Gili J.M., Sardá R., Madurell T., et al. 2013. Zoobenthos. In: Goffredo S., Dubinsky Z. (eds). The Mediterranean Sea: Its History 
and Present Challenges. Springer, Germany.

Gómez S., Lloret J., Demestre M. 2006. The decline of the artisanal fisheries in Mediterranean coastal areas: the case of Cap de Creus (Cape Creus). Coast. Manage. 34: 217-232. http://dx doi.org/10.1080/08920750500531389

Grau A.M. 2008. Review of the state of Mediterranean and Black Sea fishery resources. In Basurco B: The Mediterranean fisheries sector. Options Méditerranéennes Ser. B 62: 97-105.

Griffiths R.C., Robles R., Coppola S.R., et al. 2007. Is there a future for artisanal fisheries in the western Mediterranean? Rome, FAO-COPEMED

Guidetti P., Bussotti S., Pizzolante F., et al. 2010. Assessing the potential of an artisanal fishing co-management in the Marine Protected Area of Torre Guaceto (southern Adriatic Sea, SE Italy). Fish. Res. 101: 180-187. http://dx.doi.org/10.1016/j.fishres.2009.10.006

Halpern B.S., Walbridge S., Selkoe K.A., et al. 2008. A Global Map of Human Impact on Marine Ecosystems. Science 319: 948-952.

http://dx.doi.org/10.1126/science.1149345

Hinz H., Prieto V., Kaiser M.J. 2009. Trawl disturbance on benthic communities: chronic effects and experimental predictions. Ecol. Appl. 19: 761-773. http://dx.doi.org/10.1890/08-0351.1

ICES. 2005. Guidance on the Application of the Ecosystem Approach to management of Human Activitiea in the European marine Environment. ICES Cooperative Research n ${ }^{\circ} 273$. 22pp.

ICES. 2013. Marine and Coastal Ecossytem-Based Risk Management Handbook. ICES Cooperative Research n ${ }^{\circ} 317.59 \mathrm{pp}$.

ICES. 2014. Marine Spatial Planning Quality Management System. ICES Cooperative Research $n^{\circ} 282.94 \mathrm{pp}$.

Institute European Environmental policy (IEEP), Nature Resource Defense Council (NRDC). 2008. Marine Protected Areas in Europe and the United States. $67 \mathrm{pp}$.

Kaiser M.J., Collie J.S., Hall S.J., et al. 2002. Modification of marine habitats by trawling activities: prognosis and solutions. Fish and Fisheries 3: 114-136. http://dx.doi.org/10.1046/j.1467-2979.2002.00079.x

Lleonart J., Lloret J., Touzeau S., et al. 1998. Mediterranean fisheries, an overview. II SAP meeting, Barcelona, 13-17/10/98. 17 pp.

Merino G., Morales-Nin B., Maynou F., et al. 2008. Assessment and bioeconomic analysis of the Majorca (NW Mediterranean) trammel net fishery. Aquat. Living Resour. 21: 99-107. http://dx.doi.org/10.1051/alr:2008027

Morgan L.E., Chuenpagdee R. 2003. Shifting gears: addressing the collateral impacts of fishing methods in U.S. waters. Washington, D.C., 52 pp.

Orejas C., Gili J.M. 2009. Caracterización física y ecológica de la franja costera, plataforma continental y cañón submarino de Cap de Creus, Spanish Council for Scientific Research.

Orejas C., Gori A., Lo Iacono C., et al. 2009. Cold-water corals in the Cap de Creus canyon, northwestern Mediterranean: spatial distribution, density and anthropogenic impact. Mar. Ecol. Prog. Ser. 397: 37-51

http://dx.doi.org/10.3354/meps08314

Pauly D. 2006. Major trends in small-scale fisheries, with emphasis on developing countries, and some implications for the social sciences. Marit. Studies 4(2): 7-22.

Pikitch E.K., Santora C., Babcock E.A. et al. 2004. EcosystemBased Fishery Management. Science 305: 346-347.

Ros J.D., Romero J., Ballesteros E., et al. 1985. Diving in blue water. The benthos. In: Margalef R (ed) Key environments. Western Mediterranean, Pergamon Press, Oxford, 62 pp.

Sardá R., Rossi S., Martí X., et al. 2012 Marine benthic cartography of the Cap de Creus (NE Catalan Coast, Mediterranean Sea). Sci. Mar. 76(1): 159-171. http://dx.doi.org/10.3989/scimar.03101.18D

Shester G.G., Micheli F. 2011. Conservation challenges for smallscale fisheries: Bycatch and habitat impacts of traps and gillnets. Biol. Conserv. 144(5): 1673-1681. http://dx.doi.org/10.1016/j.biocon.2011.02.023

Scott A. 1993. Obstacles to fishery self-government. Mar. Resour. Econ. 8: 187-199.

Stelzenmüller V., Maynou F., Martín P. 2007. Spatial assessment of benefits of a coastal Mediterranean Marine Protected Area. Biol. Conserv. 136: 571-583. http://dx.doi.org/10.1016/j.biocon.2007.01.002

Stergiou K.I., Petrakis G., Politou C.Y. 1996. Small-scale fisheries in the South Euboikos Gulf (Greece): species composition and gear competition. Fish. Res. 26: 325-336. http://dx.doi.org/10.1016/0165-7836(95)00424-6

Tesi T., Puig P., Palanques A., et al. 2010. Lateral advection of organic matter in cascading-dominated submarine canyons. Progr. Oceanogr. 84(3/4): 185-203. http://dx.doi.org/10.1016/j.pocean.2009.10.004

Thayer G.W., Wolfe D.A., Williams R.B. 1975. The Impact of Man on Seagrass Systems. Am. Sci. 63: 288-296.

Thrush S.F., Hewitt J.E., Cummings V.J. et al. 1998. Disturbance of the marine benthic habitat by commercial fishing: Impacts at the scale of the fishery. Ecol. Appl. 8(3): 866-879. http://dx.doi.org/10.1890/1051-0761(1998)008[0866:DOTMB $\mathrm{H}] 2.0 . \mathrm{CO} ; 2$

Tillin H.M., Hiddink J.G., Jennings S., et al. 2006. Chronic bottom trawling alters the functional composition of benthic invertebrate communities on a sea-basin scale. Mar. Ecol. Progr. Ser. 318: 31-45. http://dx.doi.org/10.3354/meps318031

Tudela S. 2000. Ecosystem effects of fishing in the Mediterranean: An analysis of the major threats of fishing gear and practices to biodiversity and marine habitats. FAO Fisheries Department (EP/INT/759/GEF). Rome, 49 pp.

Turner S.J., Thrush S.F., Hewitt J.E., et al. 1999. Fishing impacts and the degradation or loss of habitat structure. Fish. Manage. Ecol. 6: 401-420. http://dx.doi.org/10.1046/j.1365-2400.1999.00167.x

Tzanatos E., Somarakis S., Tserpes G., et al. 2006. Identifying and classifying small-scale fisheries métiers in the Mediterranean: A case study in the Patraikos Gulf, Greece. Fish. Res. 81: $158-168$. http://dx.doi.org/10.1016/j.fishres.2006.07.007

Würtz M. 2012. Mediterranean Submarine Canyons: Ecology and Governance. Gland, Switzerland and Málaga, Spain: IUCN, 216 pp. 